\begin{abstract}
山田 一 郎**
Rebound Characteristics of a Uniform Beam Colliding with a Rubber Stopper

Ichiro YAMADA

In data communication $\mathrm{I} / \mathrm{O}$ equipment, many colliding vibrations of mechanical components are observed. Rebounds of the components often prevent the equipment from operating at a high speed. In order to decrease these rebounds, this paper discusses the rebound of a uniform beam colliding with a rubber stopper. Replacing a rubber stopper with 3-element viscoelastic model, the colliding vibration of a uniform beam is analyzed. Computed results are as follows: (1) Optimal stopper position that minimizes the rebound exists on the beam. (2) The larger spring constant ratio $r$ of the stopper is, the smaller the rebound becomes. (3) The larger press angle $\varphi_{s}$ is, the smaller the rebound becomes, but the optimal stopper position is unchanged. Experimentally, these results are confirmed. Additionally, this paper describes that the replacement of a rubber stopper with 3-element model is reasonable, and that three constants of the model can be estimated from the experimental data on impact
\end{abstract} force and deformation.

\section{1. 緒訔}

データ通信用入出力機器, 継電器等においては構成部 品の衝突振動が数多く見られるが,これら部品のは水返 りが機構の高速化の妨げとなることが多い.コンピュー タ周辺機器であるラインプリンタにおいても, 印字ハン マあるいはその駆動レバーがゴムストッパに衝突，停止 する際のはね返りを防ぐことが高速かつ良好な印字動作 を実現する上で重要となる.

一般に, 部品のは社返り現象は絽返し衝突を伴う複雑 な現象であるため, 従来は衝突時の局部变形を無視し, 反発係数によって便宜的に衝突時のエネルギ損失を与兄 て扱ったものが多(1) 7). しかしながら, 部品のは社返 り特性を詳細に検討するには, 衝突時の局部変形を考虑 する必要があると思われる，局部変形によるエネルギ損 失を考慮した検討には, 被衝突体を粘弾性模型で表した り8), 反発力に履歴特性を仮定したもの9)があるが，いず れも単純な 1 自由度振動系の衝突を扱ったものである. また， 2 自由度振動系とば社要素との衝突について高次 振動がは放返り量に及ぼす影響を検討したもの10）あ るが, エネルギ損失は考慮されていない.

そこで本報告では衝突振動の具体例として, 前述のラ

* 原稿受付 昭和 52 年 9 月 8 日. 昭和 51 年度 精機学会秋 季大会学術講演会 (昭和 51 年 10 月 14 日) および精機学 会昭和 52 年度関西地方定期学術講演会 (昭和 52 年 6 月 8 日) にて発表.

** 正会員 日本電信電話公社武蔵野電気通信研究所(武蔵 野市緑町 3-9-11)
インプリンタ印字機構に特ける衝突振動をとり上げ, 衝 突部品を分布定数振動系である一様はりに, ゴムストッ パを 3 要素粘弾性模型にモデル化して解析を行い, 数值 計算によっては权返り特性を明らかにするとともにこ れを実験で確認した。 また, 実験に先立って, ゴムスト ッパの定数推定方法および 3 要素模型近似の妥当性につ いて検討してある.

\section{2. 衝突振動の解析}

衝突振動系のモデルを図 1 亿示す。衝突部品は回転支 持された一様はりにモデル化されており, 密度 $\rho$, 断面 積 $A$, ヤング率 $E$, 断面 2 次モーメント $I$ である. また, このはりは回転軸 $\mathrm{Q}$ 回りの慣性モーメント $J て ゙$ 表され る剛体部をもち，復㷌ばね $k_{s}$ の復元力によってストッ パ飞衝突する.ここで, 回転軸 Q と復㷌ばねの取付位置 $\mathrm{R}$ の距離 $l_{s}$ である. 一方, ゴムストッパは 3 要素粘弾性 模型にモデル化されており, ばね定数 $k_{1}, k_{2}$, 粘性減衰

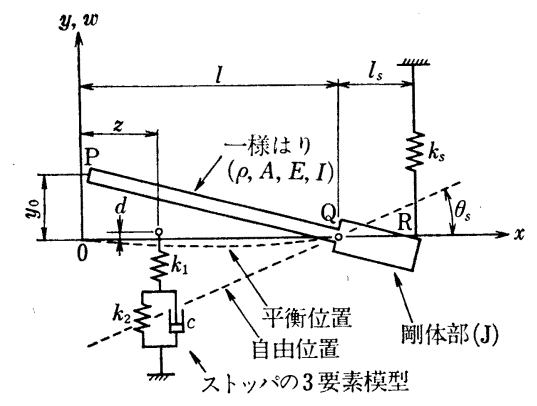

図 1 衝乫振動系のモデル 


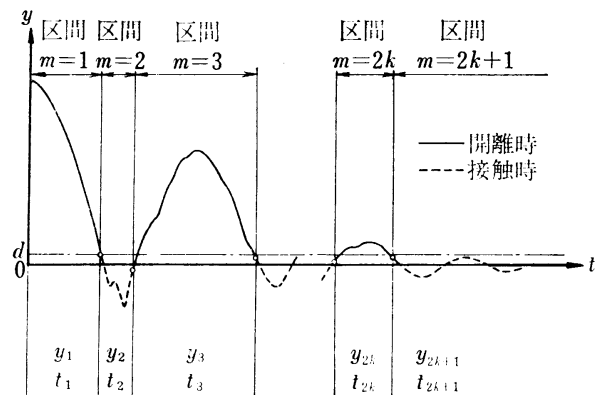

図 2 衝突振動の模式図

係数 $c$ である. 最も簡単な粘弾性模型としては, 2 要素 のマクスウェル模型とフォークト模型がある. しかし, マクスウェル模型には静止時の平衡位置が定まらない久 点があり, またフォークト模型には衝突した瞬間の衝撃 カが 0 とならない欠点があるので，本報告では，このよ らな欠点のない 3 要素模型を用いた。

はり先竡 $\mathrm{P}$ の平衡位置を座標原点 $\mathrm{O}$ とし, 回転軸 $\mathrm{Q}$ 方向にはりの位置座標 $x$ とストッパ位置 $z$ を, これらと 直角方向にはりの変位 $y$ とストッパの変位 $w$ をとる. ま た, はり先端 $\mathrm{P} の$ 初期変位を $y_{0}$, ストッパの自由位置を $d$ とする.ささらに，はりの自由位置が $x$ 軸となす角度を 押付角 $\theta_{s}$ 之定義して, 復帰ば称の押付けの強さを表す。

\section{1 はりの衝突振動}

はりがストッパに繰返し衝突するときの運動は, はり がストッパと離れている区間（開離時）とはりがストッ 心に接触している区間（接触時）に分汁られる. 図 2 に 示すように各区間を添字 $m$ で表し，開離直後あるいは 接触值後を各区間の時間原点 $\left(t_{m}=0\right)$ とする. ここで, $m=2 k-1$ は開離時を， $m=2 k$ は接触時を表す.ただし， $k$ は自然数.

区間 $m$ に拈いて，時刻 $t_{m}=0$ でのはりの变位分布を $u_{m}(x)$, 速度分布を $v_{m}(x)$, はりがストッパから受ける 衝撃力を $f_{m}\left(t_{m}\right)$ とすると, はりの変位 $y$ が長さ $l$ に比 べて小さい場合には, 無次元化されたはりの運動方程式, 初期条件，境界条件はそれぞれ以下のようになる.

[運動方程式]

$$
\frac{\partial^{2} Y_{m}\left(X, \tau_{m}\right)}{\partial \tau_{m}^{2}}+\frac{\partial^{4} Y_{m}\left(X, \tau_{m}\right)}{\partial X^{4}}=F_{m}\left(\tau_{m}\right) \cdot \delta(X-Z)
$$

ただし， $m=2 k-1$ のときは $F_{m}\left(\tau_{m}\right)=0$, また, $\delta(X)$ はディラックのデルタ関数である.

〔初期条件〕

$$
Y_{m}(X, 0)=\xi_{m}(X), \quad \frac{\partial Y_{m}}{\partial \tau_{m}}(X, 0)=r_{/ m}(X)
$$

[境界条件]

$$
\begin{aligned}
& \frac{\partial^{2} Y_{m}}{\partial X^{2}}\left(0, \tau_{m}\right)=\frac{\partial^{3} Y_{m}}{\partial X^{3}}\left(0, \tau_{m}\right)=Y_{m}\left(1, \tau_{m}\right)=0 \\
& \frac{\partial^{2} Y_{m}}{\partial X^{2}}\left(1, \tau_{m}\right)+\lambda \frac{\partial^{3} Y_{m}}{\partial \tau_{m}^{2} \partial X}\left(1, \tau_{m}\right) \\
& \quad+\kappa_{s}\left\{\frac{\partial Y_{m}}{\partial X}\left(1, \tau_{m}\right)-\varphi_{s}\right\}=0
\end{aligned}
$$

ここに, 式中の無次元量は次のように定義されている.

$$
\left\{\begin{array}{l}
Y_{m}\left(X, \tau_{m}\right)=\frac{y_{m}\left(x, t_{m}\right)}{y_{0}}, \quad \tau_{m}=\omega t_{m}, \quad \omega=\frac{1}{l^{2}} \sqrt{\frac{E I}{\rho A}}, \\
X=\frac{x}{l}, \quad Z=\frac{z}{l}, \quad F_{m}\left(\tau_{m}\right)=\frac{f_{m}\left(t_{m}\right) \cdot l^{3}}{E I y_{0}}, \\
\xi_{m}(X)=\frac{u_{m}(x)}{y_{0}}, \quad \eta_{m}(X)=\frac{v_{m}(x)}{\omega y_{0}}, \\
\lambda=\frac{J}{\rho A l^{3}}, \quad \kappa_{s}=\frac{k_{s} l l_{s}^{2}}{E I}, \quad \varphi_{s}=\frac{l \theta_{s}}{y_{0}}
\end{array}\right.
$$

これらより,はりの变位 $Y_{m}\left(X, \tau_{m}\right)$ は衝突しないとし たときの変位 $Y_{m, 0}\left(X, \tau_{m}\right)$ と衝撃力 $F_{m}\left(\tau_{m}\right)$ による変 位の和として式 (4)で, はりの速度は式 (5)で与えられる.

$$
\left\{\begin{aligned}
Y_{m}\left(X, \tau_{m}\right)= & Y_{m, 0}\left(X, \tau_{m}\right) \\
& +\int_{0}^{\tau_{m}} \mathrm{U}\left(X, Z, \tau_{m}-\tau\right) \cdot F_{m}(\tau) \mathrm{d} \tau \\
= & \sum_{i=1}^{\infty} \Xi_{i}(X)\left(A_{m, i} \cos \beta_{i}{ }^{2} \tau_{m}\right. \\
& \left.+B_{m, i} \sin \beta_{i}^{2} \tau_{m}\right)-\varphi_{s}(1-X) \\
& +\int_{0}^{\tau_{m}} \mathrm{U}\left(X, Z, \tau_{m}-\tau\right) \cdot F_{m}(\tau) \mathrm{d} \tau \\
\frac{\partial Y_{m}}{\partial \tau_{m}}\left(X, \tau_{m}\right)= & \sum_{i=1}^{\infty} \Xi_{i}(X) \cdot \beta_{i}{ }^{2}\left(-A_{m, i} \sin \beta_{i}{ }^{2} \tau_{m}\right. \\
& \left.+B_{m, i} \cos \beta_{i}^{2} \tau_{m}\right) \\
& +\int_{0}^{\tau_{m}} \frac{\partial U}{\partial \tau_{m}}\left(X, Z, \tau_{m}-\tau\right) \cdot F_{m}(\tau) \mathrm{d} \tau(5)
\end{aligned}\right.
$$

ただし， $m=2 k-1$ のとき $F_{m}(\tau)=0$.

ここで, $\mathrm{U}\left(X, Z, \tau_{m}\right)$ はインパルス応答で

$$
\begin{aligned}
\mathrm{U}\left(X, Z, \tau_{m}\right)= & \sum_{i=1}^{\infty} \frac{\Xi_{i}(X) \cdot \Xi_{i}(Z)}{\left\{\Xi_{i}(X)\right\}^{2} \mathrm{~d} X+\lambda\left\{\Xi_{i}^{\prime}(1)\right\}^{2}} \\
& \times \frac{\sin \beta_{i}{ }^{2} \tau_{m}}{\beta_{i}{ }^{2}}
\end{aligned}
$$

$\Xi_{i}(X)$ は $i$ 次規準関数で

$$
\Xi_{i}(X)=\cosh \beta_{i} X+\cos \beta_{i} X
$$

$$
-\frac{\cosh \beta_{i}+\cos \beta_{i}}{\sinh \beta_{i}+\sin \beta_{i}}\left(\sinh \beta_{i} X+\sin \beta_{i} X\right)
$$

$\beta_{i}{ }^{2}$ は $i$ 次固有角振動数で, $\beta_{i}$ は次式を満たす $i$ 次固有 
值.

$$
\beta(\cosh \beta \sin \beta-\sinh \beta \cos \beta)
$$

$$
+\left(\lambda \beta^{4}-\kappa_{s}\right)(1+\cosh \beta \cos \beta)=0
$$

$A_{m, i}, B_{m, i}$ は区間 $m$ の初期条件によって定まる定数で

$$
\left.\begin{array}{c}
A_{m, i}=\frac{\int_{0}^{1} \xi_{m}^{*}(X) \cdot \Xi_{i}(X) \mathrm{d} X+\lambda \xi_{m}^{* \prime}(1) \cdot \Xi_{i^{\prime}}(1)}{\int_{0}^{1}\left\{\Xi_{i}(X)\right\}^{2} \mathrm{~d} X+\lambda\left\{\Xi_{i}{ }^{\prime}(1)\right\}^{2}} \\
B_{m, i}=\frac{\int_{0}^{1} \eta_{m}(X) \cdot \Xi_{i}(X) \mathrm{d} X+\lambda \eta_{m}(1) \cdot \Xi_{i}(1)}{\int_{0}^{1}\left\{\Xi_{i}(X)\right\}^{2} \mathrm{~d} X+\lambda\left\{\Xi_{i^{\prime}}(1)\right\}^{2}}
\end{array}\right\}
$$

ただし， $\xi_{m}{ }^{*}(X)=\xi_{m}(X)+\varphi_{s}(1-X), \quad$ は $X$ に関する 微分.

\section{2 ストッパの運動}

3 要素模型で表されるストッパの変位は, 区間 $m=1$ ではストッパは静止しているので

$$
W_{1}\left(\tau_{1}\right)=0
$$

区間 $m \geqq 2$ では，時刻 $\tau_{m}=0$ でストッパの変位とはりの $X=Z$ の変位が等しい条件 $W_{m}(0)=Y_{m}(Z, 0)=\xi_{m}(Z)$ を考罳す机ば次式で与兄られる。

$$
\begin{aligned}
W_{m}\left(\tau_{m}\right)= & D+\left\{\xi_{m}(Z)-D\right\} \mathrm{e}^{-\frac{\kappa_{2}}{\mu} \tau_{m}}-\frac{1}{\kappa_{1}} F_{m}\left(\tau_{m}\right) \\
& -\frac{1}{\mu} \int_{0}^{\tau_{m}} \mathrm{e}^{-\frac{\kappa_{2}(\tau m-\tau)}{\mu}} \cdot F_{m}(\tau) \mathrm{d} \tau
\end{aligned}
$$

ただし， $m=2 k-1$ のとき $F_{m}(\tau)=0$, また，式中の新し い無次元量は次のように定義されている.

$$
\left\{\begin{array}{l}
W_{m}\left(\tau_{m}\right)=\frac{w_{m}\left(t_{m}\right)}{y_{0}}, \quad \kappa_{1}=\frac{k_{1} l^{3}}{E I}, \\
\kappa_{2}=\frac{k_{2} l^{3}}{E I}, \mu=\frac{c \omega l^{3}}{E I}, \\
D=\frac{d}{y_{0}}=\frac{6-\kappa^{*}(1-Z)^{3} Z}{6(1-Z)+\kappa_{s}\left(Z^{3}-3 Z+2\right)} \cdot \frac{\kappa_{s}}{\kappa^{*}} \varphi_{s} \\
\text { ただし }, \kappa^{*}=\frac{\kappa_{1} \kappa_{2}}{\kappa_{1}+\kappa_{2}}
\end{array}\right.
$$

\section{3 衝擊 カ}

はりとストッパが接触している条件 $Y_{m}\left(Z, \tau_{m}\right)=W_{m}$ $\left(\tau_{m}\right)$ 飞式 (4), (11) を用い机ば, 衝撃力 $F_{m}\left(\tau_{m}\right)$ 飞ついて のポアソン型積分方程式 (12) が導かれる.

$$
F_{m}\left(\tau_{m}\right)=F_{m, 0}\left(\tau_{m}\right)-\int_{0}^{\tau m} K\left(\tau_{m}-\tau\right) \cdot F_{m}(\tau) \mathrm{d} \tau
$$

ここで

$$
\left\{\begin{array}{r}
F_{m, 0}\left(\tau_{m}\right)=\kappa_{1}\left[\left\{D-Y_{m, 0}\left(Z, \tau_{m}\right)\right\}\right. \\
\left.-\left\{D-\xi_{m}(Z)\right\} \mathrm{e}^{-\frac{\kappa_{2}}{\mu} \tau_{m}}\right] \\
K\left(\tau_{m}\right)=\kappa_{1}\left\{\mathrm{U}\left(Z, Z, \tau_{m}\right)+\frac{1}{\mu} \mathrm{e}^{-\frac{\kappa_{2} \tau_{m}}{\mu}}\right\}
\end{array}\right.
$$

したがって, 積分方程式 (12) の解として衝撃力 $F_{m}\left(\tau_{m}\right)$ が求められるので, 区間 $m=1$ の初期条件を与光れば, 式 (4),(5), (11)を繰返し用いてはりの衝突振動を計算する ことができる.ここでは運動開始時点で, はりが直線坴 位分布をもち, 静止しているとして, 区間 $m=1$ の初期 条件を次式で与える.

$$
\xi_{1}(X)=1-X, \quad \eta_{1}(X)=0
$$

\section{3. はね返り特性の計算結果}

1 回目のは社返り以降 (区間 $m \geqq 3)$ に, はり先端 $\mathrm{P}(X$ $=0)$ がとる最大変位をは权返り量 $Y_{\max }$ と定義する. 計 算では最大 5 回目のは社返り（区間 $m=11$ ) までを考虑 してはね返り量を求めた, ここで, 3 要素模型の二つのば

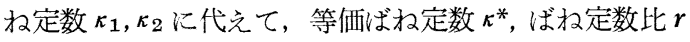

$$
\left\{\begin{array}{l}
\kappa^{*}=\frac{\kappa_{1} \kappa_{2}}{\kappa_{1}+\kappa_{2}}=\frac{l^{3}}{E I} \cdot \frac{k_{1} k_{2}}{k_{1}+k_{2}} \\
r=\frac{\kappa_{1}}{\kappa_{2}}=k_{1} \\
k_{2}
\end{array}\right.
$$

を用いる.すると, 前章に示した解析より, は权返り量 に影響を与兄る衝突振動系のパラメータは， $Z$ ：ストッ パ位置， $\kappa^{*}$ ：ストッパの等価ばね定数， $r$ ：ストッパの ばね定数比， $\mu$ ：ストッパの粘性減衰係数， $\varphi_{s}$ ：押付角， $\lambda$ : 剛体部の慣性モーメント， $\kappa_{s}$ ：復㷌ばねのばね定数 の七つの無次元量に整理される.

後述の上うに，は双返り量はストッパ位置によって大 きく変化するので，ここでは，は权返り量とストッバ位 置の関係偖着目しては悋返り特性を整理し，図 3〜図 6 飞示す。図中, $n=5$ の曲線は 1 次から 5 次までの振動 モードを考慮して求めた計算結果である。は权返り量の 計算精度としては，5次の振動モードまでを考慮すれば 十分であることを確認している．また， $n=5$ の計算結 果と同時に，1次の振動モードの及を考慮した $n=1$ の 計算結果を示し, 両者の差によって高次振動（2 次以上 の振動）がは社返り量に及ぼす影響を明らかにした。

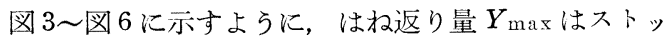
位置 $Z$ に大きく影響され，はね返り量を最小とするス トッパの最適位置が存在する。また，同じく図3〜図 6 より，高次振動がは亦返り量に及ぼす影響の大きいこと がわかる、ただし，ストッパ位置 $Z$ が回転軸 $(Z=1)$ に 近いところでは高次振動の影響は小さい。

ストッパの定数に関係する等価ばね定数 $\kappa^{*}$, ばね定数 比 $r$, 粘性減衰係数 $\mu$ がは衩返り量に及ぼす影響を検討 してみる. 図 3 は等価ばね定数 $\kappa^{*}$ の影響を示す。社が 大きくなると、ストッパ位置が回転軸に近いところでは, はね返り量は大きくなる。これ対し，ストッパ位置が 


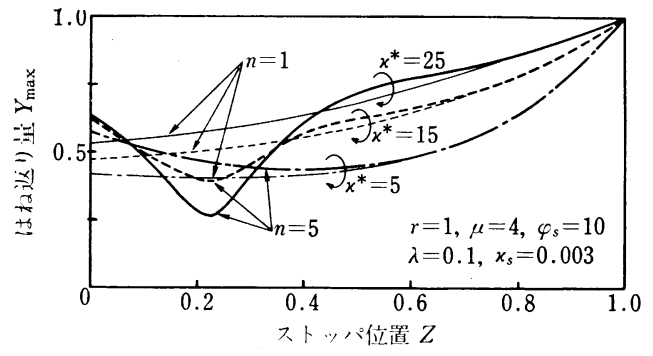

図 3 等価ばね定数 $\kappa$ *の影響

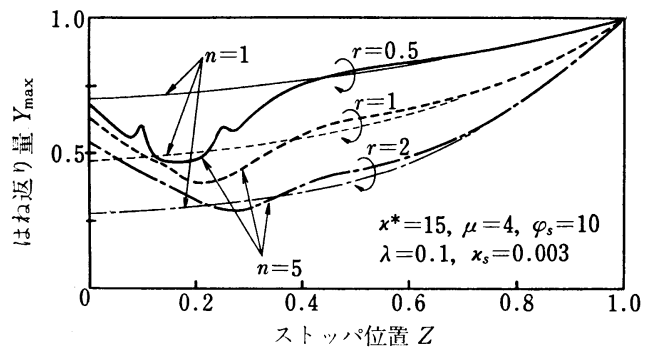

図 4 ばね定数比 $r$ の影響

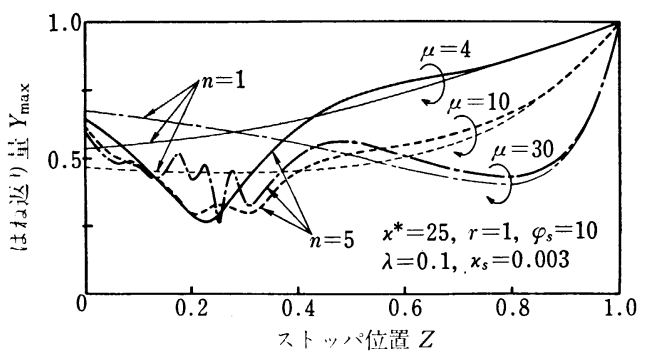

図 5 粘性減衰係数 $\mu$ の影響

はりの先端に近いところ（図では $Z=0.2$ 付近）では， $\kappa^{*}$ が大きくなると，高次振動の影響では权返り量は小さく なり,ここにストッパの最適位置が現れる. 図 4 にばね 定数比 $r$ の影響を示す， $r$ が大きくなるにつれて，はね 返り量は小さくなる。このとき，ストッパの最適位置は 回転軸方向に移動していく. 図 5 は粘性減哀係数 $\mu$ の影 響を示す， $\mu$ が大きくなると，ストッパ位置が回転軸に 近いところでは，は社返り量は小さくなる，また，スト ッパ位置がはり先端に近いところでは， $\mu$ が大きくなる と， $\mu=30$ の曲線にみられるようにストッパ位置によっ てはね返り量が激しく変化するようになる。

図 6 亿押付角 $\varphi_{s}$ の影響を示す。 $\varphi_{s}$ が大きくなるにつ れて，は将返り量は減少するが，減少の割合は次第に小 さくなる，このときストッパの最適位置は変化しない，

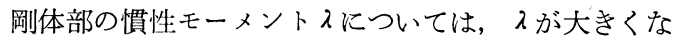
るにつれて, ストッパの最適位置が回転軸方向に移動し

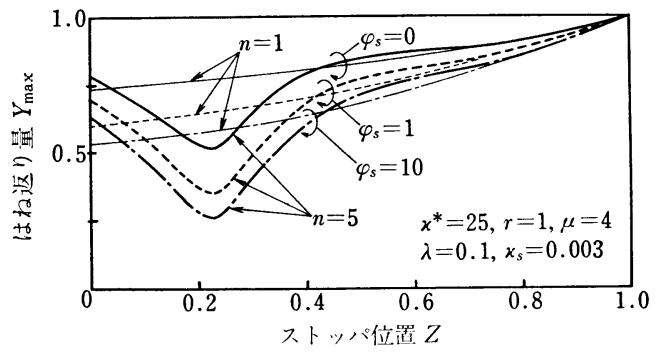

図 6 押付角 $\varphi s$ の影響

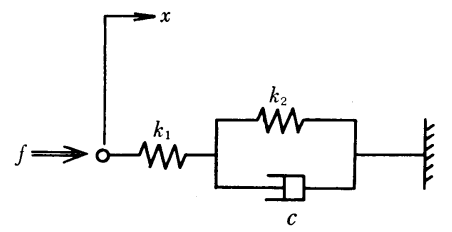

図 73 要素模型と座標

ていく傾向がみられた。また，復州ばねのばね定数 $\kappa_{s}$ は $\kappa_{s}$ が小さい範囲 $\left(\kappa_{s}=0.0003 \sim 0.03\right)$ では, はね返り量 にほとんぞ影響を及ぼさなかった。

以上の結果より，は社返りを防ぐ上で，(1)ストッパを 最適位置に設定すること, (2) ば㸚定数比 $r$ の大きなスト ッパを用いること，(3) 適当な押付角 $\varphi$ をを与兄ることが 重要であることが示される，等価ば社定数 $\kappa^{*}$ が大きい 場合には，ストッパ位置の設定が特に重要となる。

\section{4. ゴムストッパの定数推定}

はね返り量を計算するには，3 要素模型で近似したス トッパの定数を求める必要がある.ここでは, ゴムスト ッパを用いて，定数の推定を行うとともに 3 要素模型近 似の妥当性を検討した。

3 要素模型の座標系を図 7 のようにとると, 衝撃力 $f$ と変位 $x$ との関係は式(16)で表される.

$$
\dot{f}+\frac{k_{1}+k_{2}}{c} f=k_{1} \dot{x}+{ }_{c}^{k_{1} k_{2}} x
$$

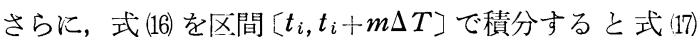
が得られる.

$$
\begin{aligned}
& \left\{f\left(t_{i}+m \Delta T\right)-f\left(t_{i}\right)\right\}+\frac{k_{1}+k_{2}}{c} \int_{t_{i}}^{t_{i}+m \Delta T} f \mathrm{~d} t \\
& \quad=k_{1}\left\{x\left(t_{i}+m \Delta T\right)-x\left(t_{i}\right)\right\}+\frac{k_{1} k_{2}}{c} \int_{t_{i}}^{t_{i}+m \Delta T} x \mathrm{~d} t
\end{aligned}
$$

式(17)を用いて定数 $k_{1}, k_{2}, c$ を推定するためには，衝 撃力 $f$ と変位 $x$ を実測する必要がある.ここでは，図 8 に示す振子落下型の打撃装置を用いて打もり（等価質量 $\left.m_{e}=2.0 \times 10^{-2} \mathrm{gs}^{2} / \mathrm{cm}\right)$ をゴムストッパに衝突させ, ゴ ムストッパに加わる衝撃力 $f$ とおもりの変位 $x$ を測定し 


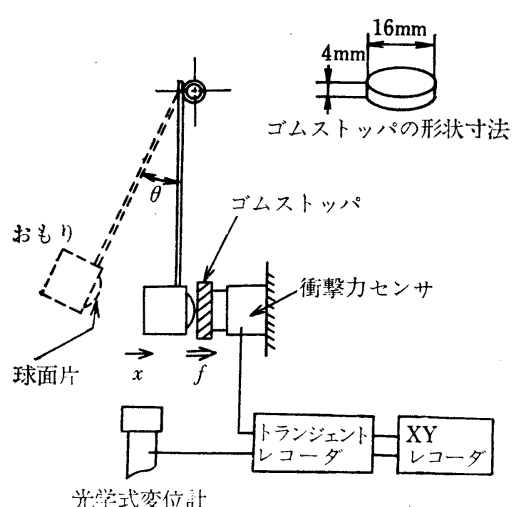

図 8 打揧装置と測定系の構成

表 1 ゴムの種類と材料特性

\begin{tabular}{|c|c|c|c|c|c|c|}
\hline ゴム 種 類 & $\mathrm{DF}-11$ & $\mathrm{DF}-12$ & $\mathrm{DF}-13$ & $\mathrm{EF}-1$ & $\mathrm{EF}-2$ & $\mathrm{EF}-3$ \\
\hline かたさ $\left(H_{S}\right)$ & 34 & 57 & 76 & 38 & 55 & 72 \\
\hline 反発弾性 $(\%)$ & 23 & 17 & 13 & 71 & 62 & 52 \\
\hline 原料 ゴム & \multicolumn{3}{|c|}{$\begin{array}{l}\text { ブチルゴム (IIR) } \\
(\text { エッソブチル\#218) }\end{array}$} & \multicolumn{3}{|c|}{$\begin{array}{l}\text { スキレン・ブタジェンュ } \\
\text { ム (SBR) (JSR \#1500) }\end{array}$} \\
\hline
\end{tabular}

表 2 定数の推定例々反発係数の比較

\begin{tabular}{|c|c|c|c|c|c|c|}
\hline \multirow{2}{*}{ ゴ ム 種 類 } & \multirow{2}{*}{$\begin{array}{c}\text { 衝突速度 } \\
v_{0} \\
(\mathrm{~cm} / \mathrm{s})\end{array}$} & \multirow{2}{*}{$\begin{array}{l}\text { 等価ばね2 } \\
\text { 定数 } k^{*} \\
(\mathrm{~kg} / \mathrm{cm})\end{array}$} & \multirow{2}{*}{\begin{tabular}{|l} 
ばね定 \\
数比 \\
$r$
\end{tabular}} & \multirow{2}{*}{$\begin{array}{c}\text { 粘性減衰係数 } \\
c \\
(\mathrm{~kg} \cdot \mathrm{s} / \mathrm{cm})\end{array}$} & \multicolumn{2}{|c|}{ 反発倸数 $e$} \\
\hline & & & & & 計算值 & 実験値 \\
\hline \multirow{3}{*}{$\begin{array}{c}\text { ブチルゴム } \\
\text { (IIR) } \\
\text { DF-12 }\end{array}$} & 92.9 & 31.2 & 6.68 & 0.0636 & 0.286 & 0.30 \\
\hline & 77.6 & 29.7 & 6.28 & 0.0602 & 0.295 & 0.30 \\
\hline & 57.5 & 24.5 & 6.25 & 0.0541 & 0.294 & 0.32 \\
\hline \multirow{3}{*}{$\begin{array}{c}\text { スチレン・ブタジ } \\
\text { エンゴム (SBR) } \\
\text { EF-1 }\end{array}$} & 92.9 & 17.9 & 1.25 & 0.0993 & 0.720 & 0.74 \\
\hline & 77.6 & 15.7 & 1.36 & 0.102 & 0.726 & 0.74 \\
\hline & 57.5 & 12.4 & 1.26 & 0.0919 & 0.736 & 0.74 \\
\hline
\end{tabular}

$v_{0}$ の值は摩擦, 空気の粘性抵抗を無視した計算値

た.なお，衝突時の片当たりを防ぐために，おもりの衝 突部には球面片（球面半径 $R=10 \mathrm{~mm}$ ）を接着した。

おもりの衝突実験より得られた衝撃力および变位の過 渡波形を $\Delta T$ 間隔に $n$ 等分し (図 9 参照)，読取った数 值を式(17) に代入，整理すると， $\xi, \eta, \zeta$ を知数とする $p$ $(=n-m+1)$ 個の方程式 (18) を得る.

$$
a_{i} \xi+b_{i} \eta+c_{i} \zeta=l_{i}, \quad(i=1,2, \cdots \cdots, p)
$$
ここで

$$
\begin{gathered}
\xi=k_{1}, \quad \eta=\frac{k_{1} k_{2}}{c}, \quad \zeta=-\frac{k_{1}+k_{2}}{c} \\
a_{i}=x\left(t_{i}+m \Delta T\right)-x\left(t_{i}\right), \quad b_{i}=\int_{t_{i}}^{t_{i+m} \cdot T} x \mathrm{~d} t \\
c_{i}=\int_{t_{i}}^{t_{i}+m_{\Delta} T} f \mathrm{~d} t, \quad l_{i}=f\left(t_{i}+m \Delta T\right)-f\left(t_{i}\right)
\end{gathered}
$$

一般に， $p>3$ の場合には最小 2 乘法を用いると, 正 規方程式の解として $\xi, \eta, \zeta$ 最確值 $\xi^{0}, \eta^{0}, \zeta^{0}$ が求めら れる. したがって，3 要素模型の定数 $k_{1}, k_{2}, c$ は式 (19) の関係より，次式のように推定できる.

$$
k_{1}=\xi^{0}, \quad k_{2}=-\frac{\xi^{0} \eta^{0}}{\xi^{0} \zeta^{0}+\eta^{0}}, \quad c=-\frac{\xi^{02}}{\xi^{0} \zeta^{0}+\eta^{0}}
$$

ここでは，打撃装置の腕の振り上げ角 $\theta$ によっておも りの衝突速度 $v_{0}$ を変えて実験を行い, ゴムストッパの 定数推定を行った. ゴムストッパとしては, 表 1 に材料 特性を示すゴムを図 8 に示すように直径 $16 \mathrm{~mm}$ ，厚さ $4 \mathrm{~mm}$ の円板に切断して用いた.

表 2 に, 衝突速度 $v_{0}$ を変えたときの反発係数 $e$ (反発 速度と衝突速度の比の絶対値) の值と推定定数を等価ば

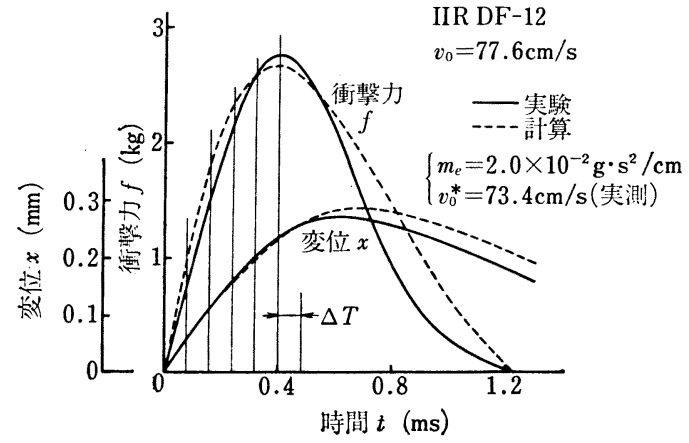

図 9 衝撃力と变位

ね定数 $k^{*}=k_{1} k_{2} /\left(k_{1}+k_{2}\right)$, ばね定数比 $r=k_{1} / k_{2}$, 粘 性減衰係数 $c$ を用いて整理した結果の一例を示す. 衝突 速度が変化しても, 反発係数の実験值はほぼ一定であり, 推定定数にも大きな差は認められない.さらに，ゴムス トッパの特性が 3 要素慔型でどの程度近似できているか を調べるために, 反発係数 $e$, 衝撃力 $f$, 変位 $x$ につい て実験結果と推定定数を用いた計算結果とを比較した. この結果, 表 2 および図 9 に示すように，かなり良く近 似できていることがわかった。 ここで, 計算結果とは剛 体と 3 要素模型の衝突として解析を行った結果に推定定 数を代入して計算したものである. 以上の検討より, ゴ ムストッパの 3 要素模型近似の妥当性が確認できた。 た，同時に，定数の推定方法の妥当性も確認できた.

\section{5. 一様はりとゴムストッパの衝突実験}

ここでは，一様はりと定数の求まったゴムストッパと の衝突実験を行って，はね返り量を実測し，解析で求め 


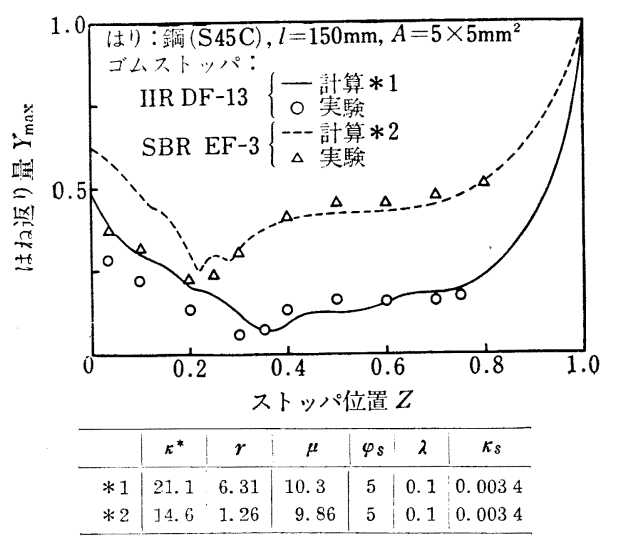

図 10 一様はりのはね返り特性 (1)

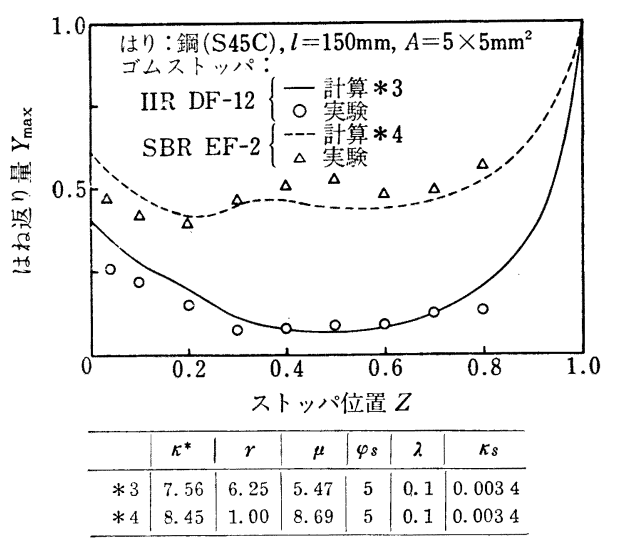

図 11 一様はりのはね返り特性（2）

たはね返り特性の確認を行った。

はりの材質は鋼 (S 45C) とし, 寸法は長さ $l=150 \mathrm{~mm}$, 断面積 $A=5 \times 5 \mathrm{~mm}^{2}$ とした。 また, ストッパ位置に対 応するはりの衝突部には，衝突時の片当たりを防ぐた め, ゴムストッパの定数推定の場合と同じ球面半径 $R=$ $10 \mathrm{~mm}$ をる, 厚さ $1 \mathrm{~mm}$ の球面片を接着した. ごム ストッパの形状寸法（図 8) も定数推定の場合と同じで ある.

実験では, 衝突部の球面片がゴムストッパに接する位 置で，はりが水平基準面に平行となるように回転軸の高

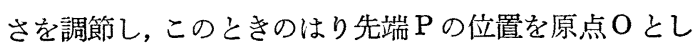

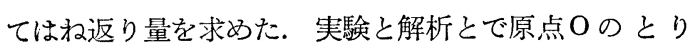
方が異なるのは，ストッパ位置の移動など実験上の容易 さを考慮したためであり，本質的な違いはない。実験に 対応させては水返り量を計算するには, ストッパの自由 位置 $D$ を $D=0$ とすればよい。

さて、はりをマグネット、に吸引して先端 $\mathrm{P}$ に初期変位 $y_{0}$ を与えて静止させた後, マグネットの励磁電流を切
り，復帰ばねの復元力によってはりをゴムストッパに衝 突させる.このときのはり先端 $\mathrm{P}$ の過渡变位波形を測定 し,は社返り量 $y_{\max }$ を求めた. ここで, $y_{0} \fallingdotseq 7 \mathrm{~mm}$ とし た.

図 10, 図 11 亿表1のゴムストッパを用いて求めたは ね返り特性の実験結果と対応する計算結果とを比較して 示す. 計算には, はりの定数として, ヤング率 $E=2.1$ $\times 10^{6} \mathrm{~kg} / \mathrm{cm}^{2}$, 密度 $\rho=7.8 \mathrm{~g} / \mathrm{cm}^{3}$ を用いた. また, ゴ ムストッパの定数としては本実験の 衝突エネルギ $E_{0} か ゙$ $E_{0} \fallingdotseq 30 \mathrm{~g} \cdot \mathrm{cm}$ であることから, これと衝突エネルギがほ ぼ等しい括もりの衝突速度 $v_{0}=57.5 \mathrm{~cm} / \mathrm{s}\left(E_{0} \fallingdotseq 33 \mathrm{~g}\right.$. $\mathrm{cm}$ ) の場合の推定値を用いた.

実験結果と計算結果とは，はね返り量およびはね返り 量を最小とするストッパの最適位置のいずれについても 比較的よく一致している. これによって, 計算で求めた はね返り特性の妥当性が確認できた。

\section{6. 結言}

機構部品のはね返り低減を目的として，一様はりがス トッパに衝突する際のはね返り特性について検討し, 以 下の結論を得た.

(1) はりと 3 要素粘弾性模型で近似したストッバとの 衝突振動の検討によれば，(i)はね返り量を最小と するストッパの最適位置が存在する, (ii) ストッパ

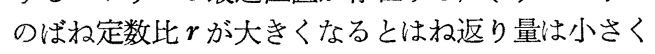
なる，(iii）押付角 $\varphi_{3}$ が大きくなるとはね返り量は 小さくなるが，ストッパの最適位置は变化しない。

(2) ゴムストッパを 3 要素模型に近似することは妥当 であり, 3 要素定数は衝撃力, 变位の実測データよ り推定できる.

最後に，本研究を行うにあたり終始ご指導いただいた 日本電信電話公社武蔵野電気通信研究所, 中川三男特別 研究室長に深く感謝いたします。

\section{参 考 文 献}

1）高村真夫, 百合野豊二, 大塚猶二: 継電器のチャッタ現 象に関する研究，通研害報, 9, 12 (1960) 1355.

2）妿藤浩子, 武井健三: 位相面による 1 自由度振動系のチ

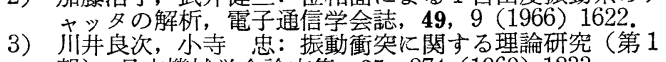
報), 日本機械学会論文集, 35, 274 (1969) 1233 .

4）少寺: 振動衝突に関する理論研究 (第 2 報), 日本機

5) 入杜博論文集, 深谷健一: 286 (1970) 923 自由度系の定常衝突振動につい 乙, 日本機械学会論文集, 37, 299 (1971) 1287.

6) W. H. Park: Mass-Spring-Damper Response to Repetitive Impact, Trans. ASME, Ser. B, 89, (1967) 587.

7）横山恭男, 小泉邦雄: 衝突振動の研究 (第 1 報), 精密 機械, 36, 11 (1970) 731 .

8）米川元庸, 村田幸嗣, 植条峰雄: 損失のある一自由度振 動系のチャッタ, 電子通信学会誌, 50, 7 (1967) 1248 .

9) 前沢成一郎, 渡辺 武: 履歴特性を持つ物体の定常㣫突 振動の解析, 日本機械学会論文集, 41，342 (1975) 420 .

10) 高村真夫, 町野俊明, 山崎真一: チャッ夕振動におよほ す高次振動の影響, 電子通信学会誌, 48, 1 (1965) 58. 